\title{
QUALITY OF LIFE IN THE POLISH URBAN CENTRES. AN ATTEMPT TO EVALUATE LARGE CITIES
}

\author{
Piotr Hajduga', Małgorzata Rogowska²
}

\begin{abstract}
The article presents current and, from the point of view of the Au-thors, important problems of quality of life in the large Polish cities. In contem-porary concepts of socio-economic development, improving the quality of life is considered one of the main strategic goals and a key element of sustainable development. Quality of life is one of the factors affecting the city's attractiveness for potential investors and residents. One of the most important perspectives of thinking about development is to ensure the highest standard of living for all residents of a given territorial unit. This is to lead to stability of the socio-economic system and maximum expansion of the group of beneficiaries of economic development. There were analysed eighteen largest urban centres. The subjects of the study are provincial cities. The presented comparison is a static approach, taking into account only one year. The purpose of this article is an attempt to evaluate the quality of life in selected Polish cities in 2018. The employed research methods are primarily a comparative analysis method and simple statistical methods that have allowed to compare and aggregate selected indicators on the quality of life in urban centres. On this basis, cities were ranked with the assumption that the cities with the highest indicator values (assuming that the given feature is a stimulant) are at the top of the ranking. An additional objective of the study is to present the condition of Polish cities in terms of population and their area, taking into account the situation in Polish regions. Finally, the study presents an analysis of the quality of life of the large Polish cities based on selected 13 indicators. The best results were achieved not only by large economically significant cities, attracting investments and residents, but also those located on the eastern wall of the country, which can be described as "more intimate" in terms of area and population, such as Rzeszów, Lublin or Olsztyn.
\end{abstract}

Key words: quality of life, city, attractiveness, competitiveness, creativity, en-trepreneurship.

JEL Classification: J17, R11

\section{Introduction}

The attractiveness and competitiveness of urban centres in Poland are not an accident. Basic local government units bring together the most talented people and the most innovative businesses, as well as extremely interesting social and cultural projects. Polish cities are centres of activity and socio-economic development. It should be noted, however, that urban development is not a linear process. Territorial units compete with one another for talents and resources, fighting for primacy at the local, regional, national, and eventually at the global level. The result of this competition depends on many factors, including national policy, global trends (globalisation, technological changes), decisions of enterprises concerning location, as well as the efficiency of local politicians (Wałachowski, 2019).

Cities are currently perceived and evaluated as centres of varying degrees of at-tractiveness and competitiveness, as well as creativity and entrepreneurship due to (Klasik, 2008):

- successive replacement of the "descending" generation of human capital with a new qualitatively better generation "entering" the age of profes-sional activity; - renovation and enrichment of equipment and institutions as well as infra-structure networks, specialised and high-level equiped;

- natural and cultural environment, historic urban and industrial structures, nurtured and enriched with new functions;

\footnotetext{
Corresponding author:

${ }^{1}$ Wroclaw University of Economics and Business, Poland.

E-mail: piotr.hajduga@ue.wroc.pl

ORCID: https://orcid.org/0000-0002-6946-8598

ResearcherID: T-4095-2018

${ }^{2}$ Wroclaw University of Economics and Business, Poland.

E-mail: malgorzata.rogowska@ue.wroc.pl

ORCID: https://orcid.org/0000-0003-1856-259X

ResearcherID: U-4635-2018
} 
- offers of places and spaces for creative and enterprising people or for cre-ative businesses in the fields of culture and science;

- the potential of the "creative class" and creative environments, as well as the entrepreneurial capital of the inhabitants of a territorial unit mobilised by the proinnovative policy of public authorities;

- permanent investment in culture, science and education infrastructure, thus obtaining unique assets "instrumenting" creative environments and creative types of activity.

New businesses and institutions, innovations in existing companies and institu-tions, innovative creative types of activity, as well as existing creative industries generating local and global effects create the vital basis and the foundation of the prosperity of urban centres, as well as the well-being of their residents. They are the lever for their sustainable development. Each territorial unit, depending on its size and rank and depending on the phase of the life cycle, is attractive and competitive, creative and entrepreneurial as far as four fundamental components are present and cooperating in it, i.e., space, people, infrastructure, and activity (Klasik, 2008).

The above-mentioned basic components of creative and attractive cities are the bearers of concepts, content, procedures, and interactions related to a certain scope either with the creativity or with the attractiveness of urban centres. It is vitally important that all key components taken together and in mutual interac-tion decide that territorial units are or are just becoming or can be shaped as creative and attractive cities. It is determined by the relations of partnership, coordination, and cooperation of various entities operating in urban centres and agglomerations (Klasik, 2008).

The main purpose of this article is an attempt to evaluate the quality of life in selected Polish cities. One of the most important perspectives of thinking about development is to ensure the highest standard of living for all residents of a given territorial unit. This is to lead to stability of the socio-economic system and maximum expansion of the group of beneficiaries of economic develop-ment. From this point of view, development is understood as improving living conditions in the following areas: communication, housing, health protection, ecology, access to green areas, and security (Wałachowski, 2019).

The subjects of the study are provincial cities. This article compares selected indicators, which are often listed in the literature on the subject and which may reflect selected elements related to the quality of life in the city in 2018. The data for analysis stems from the Local Data Bank are created by the Central Statistical Office.

\section{Quality of life in urban centres}

In contemporary concepts of socio-economic development, improving the quality of life is considered one of the main strategic goals and a key element of sustainable development (Borys, 2003; Brol, 2001; Szewczuk, 2011, 33; Throsby, 2010). This is also reflected in the local development strategies of numerous Polish territorial units, where increasing the quality of the residents' lives is emphasized mostly in visions and missions formulated in documents as well as for strategic and operational goals. Interest in the quality of life is not only related to the definition of the city authorities' obligations to the community as creating the best conditions for living and working, but also to the fact that the quality of life is becoming one of the strategic determinants of decisions on the location of business activities and new investments. The justification for this thesis can be found, among others, in work by R.J. Rogerson (1999), which deals with competitive struggle between urban centres, and distinguishes quality of life as one of the factors affecting the city's attractiveness for potential investors and residents. The quality of life also appears in the works of R. Florida (2010) and his creative class theory (Sanetra-Szeliga, 2017).

The quality of life is the subject of numerous studies within various research disciplines, i.e., economics, political sciences, psychology, philosophy or medical sciences (Panek and Zwierzchowski, 2019). In the colloquial sense, the term is a subjective category, depending, among others, on attitudes and lifestyle, values, cultural circle, as well as tradition (KrólikowskaTomczak, 2016). The concept of quality of life appeared in the 1960s as an alternative to the dominant goal of social development, which was the increase in the material standard of living, or the increase in well-being. In economic sciences, the term prosperity is identified with economic well-being (welfare) and means the usefulness of a specific set of goods and services. In practice, welfare is understood as the usefulness of income necessary to purchase these goods and services (Kot, 2004).

There are numerous different definitions of quality of life in the literature. In the broadest sense, this concept is identified with welfare, well-being, or life satisfaction (Yuan, Yuen and Low, 1999). This term is often equated with such terms as "standard of living", sometimes also called "level of living". The standard of living is related to the needs met by the consumption of material goods and services. Therefore, it can be called an "objective level of quality of life" or "objective quality of life" (Borys, 2003), and its estimation should take into account such elements as: health, nutrition, education, employment and working conditions, housing, social security, clothing, recreation, and human freedom. A background for assessing the standard of living should be to de-scribe aggregate consumption, savings, and the transport system, as well as tele-communications, the postal system, revenues and expenses, as well as the population and labour force. The standard of living 
Vol. 6, No. 4, 2020

Table 1

Selected indicators for measuring quality of life in Poland according to the Central Statistical Office

\begin{tabular}{|c|c|}
\hline Area & Selected indicators \\
\hline Material living conditions & $\begin{array}{l}\text { - Average monthly disposable income } \\
\text { - Poor/good assessment of the state of the household budget (expressed in \%) }\end{array}$ \\
\hline Main type of activity, work & $\begin{array}{l}\text { - Employment rate/unemployment rate } \\
\text { - Overtime employment } \\
\text { - Employed persons under a fixed-term contract } \\
\text { - Degree of job satisfaction }\end{array}$ \\
\hline Health & $\begin{array}{l}\text { - Good / bad health self-assessment indicator } \\
\text { - Cancellation of doctor visits due to financial rea-sons/waiting time }\end{array}$ \\
\hline Education & $\begin{array}{l}\text { - Number of people who speak foreign languages } \\
\text { - Number of people who regularly use the computer and the Internet } \\
\text { - Percentage of people with higher education }\end{array}$ \\
\hline Free time and social relations & $\begin{array}{l}\text { - Lack of free time } \\
\text { - Satisfaction with the quantity and quality of free time } \\
\text { - Social isolation indicator } \\
\text { - Trust in other people }\end{array}$ \\
\hline Economic and physical security & $\begin{array}{l}\text { - Security at home } \\
\text { - Inability to cover unexpected expenses }\end{array}$ \\
\hline Rule of law and civic activity & $\begin{array}{l}\text { - Trust in the Sejm, Senate, government and local au-thorities } \\
\text { - Turnout in elections to the Sejm } \\
\text { - Volunteers }\end{array}$ \\
\hline Environmental quality & $\begin{array}{l}\text { - Noise level } \\
\text { - Environment pollution } \\
\text { - Satisfaction with recreational and green areas }\end{array}$ \\
\hline Subjective well-being & $\begin{array}{l}\text { - Life satisfaction } \\
\text { - Indicator of good/bad mood }\end{array}$ \\
\hline
\end{tabular}

Source: own study based on CSO data

in this approach was to be measured by means of quantitative, i.e., "objective" indicators (International Definition..., 1961). However, the quality of life can also be determined through qualitative research, and then we speak of a "subjective level of quality of life", a term often used interchangeably with "level of contentment", "satisfaction", "well-being” or "happiness". This approach explores the subjective approach to the lives of individuals in terms of their hedonistic (positive emotions and feelings) and cognitive (cognitive satisfaction with life) experiences (Diener and Suh, 1997).

From the point of view of the urban centre and its development, attention should be paid to an objective and subjective approach to the quality of life. That is why the present discussion employs a definition, which combines both approaches: quality of life is the extent, to which the objective needs of the individual are met in conjunction with the subjective assessment of their well-being. Quality of life defined in this way can be measured using qualitative and quantitative indicators (Costanza, Fisher, Ali et al., 2008).

The quality of life is analysed by statistical offices, which take into account the objective conditions and subjective well-being of the respondents (Table 1).

The concept of quality of life in territorial units should be supplemented with a spatial perspective. The city has a material dimension: it is its area, infrastruc-ture, number of inhabitants, enterprises, and universities located in its area. The urban centre is also a network of intangible relationships and opportunities which it creates for its inhabitants. It is the level of satisfying the needs of socie-ty that is identified with the quality of life in the city (Yuan et al., 1999). The needs of residents of territorial units are diverse and complex. However, it is economic growth, rational use of resources, and environmental protection, which are indicated as the main directions of the city's development, having a direct impact on the quality of life of its inhabitants. Parallel monitoring of these areas should lead to sustainable development (Yuan et al., 1999).

\section{Demographic conditions for the development of Polish cities}

The Polish urban centres are influenced by various factors (endogenous and exogenous), due to which their situation changes. Territorial units are developing, experiencing periods of stagnation, decline, marginalisation, only to develop again. Prosperity cycles are intertwined with periods of stagnation and regression (Cheshire, Nathan and Overman, 2014). The developmental path of each city is, in fact, different, because a given territorial unit is subject to various conditions that affect it. The strength of the impact of these factors in individual periods of city life varies. In urban centres, there are multidimensional relations 
between individual elements of the city system, as well as between the city and its surroundings. The complexity and diversity of processes and phenomena occurring in a given territorial unit and its surroundings mean that there is a considerable number of factors affecting the development of cities, both in its strength and pace, and impacting the direction of the development. However, it should be noted that the strength, pace and direction of the impact of individual factors on different elements of urban systems will vary (Boryczka, 2019).

The main challenge currently faced by territorial units is, first and foremost, to ensure economic, social and territorial cohesion (European Commission, 2010). The high quality of city management should lead to the integration of urban areas in spatial and social dimensions. Creating a competitive society, which is reachable for all and taking into account the mobility of the labour market, is important for this purpose. Creating social capital should be based on maintaining and developing social identity by building conditions for social integration, and social inclusion of, among others, the growing group of people aged $60+$ (GUS, 2018).

At present, the aging population is a challenge for the social policy im-plemented in Poland. Today, it is a demographic process of unprecedented scale and intensity, which is particularly noticeable in urban centres. Unfavourable demographic changes associated with low birth rates lead to an increase in the participation of older people in society. The effects of this phenomenon include changes in the labour market and increased outlays from public funds for the elderly, among others in healthcare, social work and institutional assistance, as well as shaping appropriate living conditions. The challenge for senior policy is to take measures that are planned and purposeful to improve the life situation of this social group (GUS, 2018).

As of January 1, 2019, the Polish settlement network included 16 voivod-ships, 314 land poviats, 66 cities with poviat rights (so-called poviats) and 2477 municipalities: 302 urban municipalities (including 66 municipalities also having poviat status), 1537 rural municipalities and 638 urban-rural municipalities (Figure 1).

940 settlement units covering the area of $22162 \mathrm{~km}^{2}$, i.e., $7.1 \%$ of the entire country, had urban status. The level of urbanisation measured by the number of urban population was $60.1 \%$. The Polish settlement network is polycentric in nature, as it is characterised by a regular distribution of cities in terms of size, a developed hierarchy structure of several levels, and a small advantage of the largest city in the capital over other

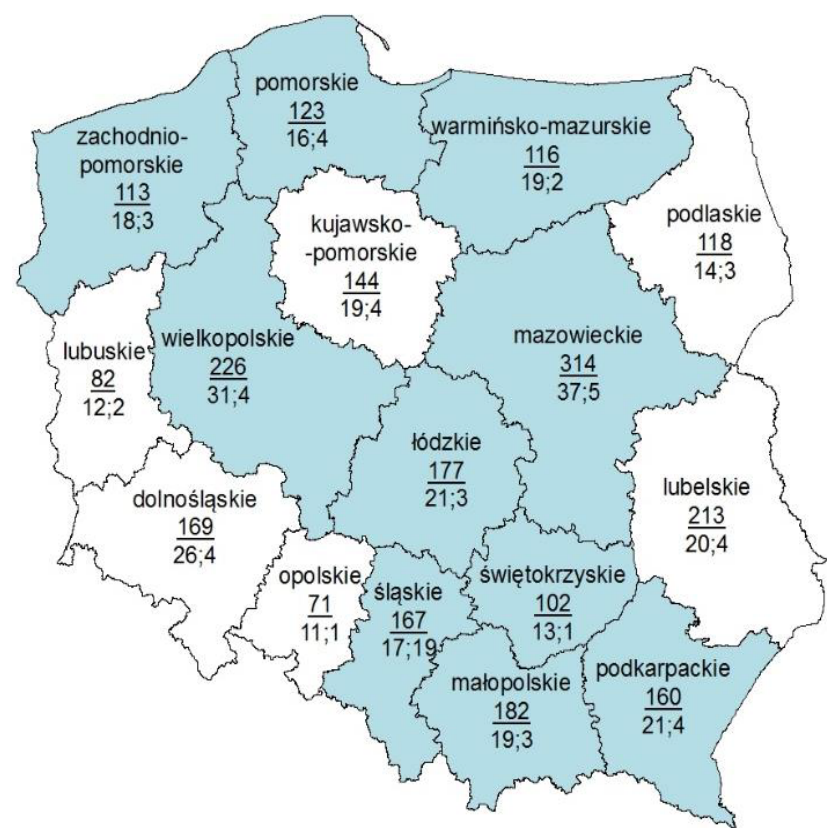

units covered by changes in territorial division

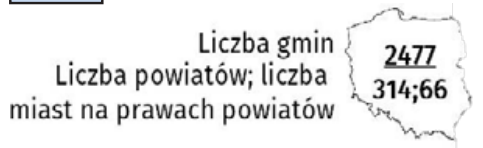

Figure 1. Number of territorial division units by January 1, 2019

Source: (GUS, 2019, p. 11) 
regional centres compared to other European countries (KPZK 2030 - MP 2012 item 252, Resolution No. 239 ...; Korcelli, 2007, pp. 87-113).

In the years 1989-2019, the total number of cities in Poland increased from 822 to 940 , i.e., by $14.4 \%$. These changes resulted from the granting of municipal rights resulting from the activities of local authorities, a manifestation of increasing self-governance and activity, as well as an expression of rebirth or creation of a new social and cultural identity, especially in the first period of transformation. The acceleration was caused by amendments to the Act on local government carried out in 1992, enabling the granting of city status not only to municipalities, but also to cities that meet the assessed urban criteria (Kosecki and Stawarz, 2005; Zaniewska, 2014).

The formation process is stimulated at the local level. It should be noted that, despite some objective criteria for granting city rights, important factors deter-mining the granting of city rights are political influences and certain decisions of a subjective nature, e.g., the demographic criterion is not always met, as some new cities have fewer than 2000 residents (Konecka-Szydłowska, 2017).

From the data presented in Table 2, it is clear that the majority of cities have been located in Greater Poland voivodship (113, i.e., $12 \%$ of all Polish cities), as well as Lower Silesian (91, i.e., 9.7\% of all Polish cities) and Masovian (88, i.e., $9.4 \%$ of all Polish cities). Of the total number of 722 small cities, i.e., those with fewer than 20 thousand inhabitants, $52.2 \%$ were located in the areas of six voivodships: Greater Poland (93), Lower Silesian (72), Masovian (63), West Pomeranian (55), Lesser Poland (49) and Kuyavian-Pomeranian (45).
In the most urbanized Silesian voivodship, there were located $17 \%$ of all Polish cities above 20000 residents.

The highest density of city networks was in the Silesian Voivodship, where there was $173.7 \mathrm{~km}^{2}$ of the voivodship's area per city. The density ratio of the network of cities below $300 \mathrm{~km}^{2}$ also pertained to the following voivodships: Lower Silesian $\left(219.2 \mathrm{~km}^{2}\right)$, Lesser Poland $\left(244.9 \mathrm{~km}^{2}\right)$, Opole $\left(261.4 \mathrm{~km}^{2}\right)$ and Greater Poland $\left(263.9 \mathrm{~km}^{2}\right)$. The northern and eastern regions of the country had lower network density, and the rarest city network in 2019 con-cerned the Lublin voivodship, where the value of the index was $523.4 \mathrm{~km}^{2}$, as well as the Podlaskie voivodship $\left(504.7 \mathrm{~km}^{2}\right)$.

Territorial differentiation of the urbanisation indicator and the structure of the urban population by the size of the city and the size of the average city are pre-sented in Table 4.

In 2019, urban population amounted to 23087.87 thousand people, i.e., $60.1 \%$ of the population of the whole country. The most urbanized was the Silesian Voivodship, where the population in cities constituted $76.7 \%$ of the total population of the Voivodship. The following voivodships had a high urbanisation rate: Lower Silesian (68.6\%) and West Pomeranian (68.5\%). In four voivodships (Lublin, Lesser Poland, Subcarpathian, Holy Crosse) the urban population constituted less than half of the total population of the given voivodship.

The average Polish city in 2019 covered $23.6 \mathrm{~km}^{2}$ of area and had 24.6 thousand residents. The largest, both in terms of area and population, was the average city of the Silesian voivodship. The smallest area was in the average city of the Warmian-Masurian voivodship,

Table 2

Density of city networks and their number by voivodships (as of January 1, 2019)

\begin{tabular}{|c|c|c|c|c|c|}
\hline \multirow[b]{2}{*}{ Specification } & \multirow{2}{*}{$\begin{array}{l}\text { Area of voi-vodship } \\
\text { per one city in } \mathrm{km}^{2}\end{array}$} & \multicolumn{4}{|c|}{ Number of cities } \\
\hline & & In total & $\begin{array}{l}\text { in urban-rural } \\
\text { mu-nicipalities }\end{array}$ & $\begin{array}{l}\text { below } 20 \text { thousand } \\
\text { residents }\end{array}$ & $\begin{array}{l}\text { over } 20 \text { thousand } \\
\text { residents }\end{array}$ \\
\hline Poland & 332.7 & 940 & 638 & 722 & 218 \\
\hline Lower Silesian & 219.2 & 91 & 56 & 72 & 19 \\
\hline Kuyavian-Pomeranian & 345.6 & 52 & 35 & 45 & 7 \\
\hline Lublin & 523.4 & 48 & 28 & 38 & 10 \\
\hline Lubusz & 325.3 & 43 & 34 & 37 & 6 \\
\hline Łódź & 414.1 & 44 & 26 & 29 & 15 \\
\hline Lesser Poland & 244.9 & 62 & 48 & 49 & 13 \\
\hline Masovian & 404.1 & 88 & 53 & 63 & 25 \\
\hline Opole & 261.4 & 36 & 33 & 30 & 6 \\
\hline Subcarpathian & 349.9 & 51 & 35 & 41 & 10 \\
\hline Podlaskie & 504.7 & 40 & 27 & 32 & 8 \\
\hline Pomeranian & 436.3 & 42 & 20 & 27 & 15 \\
\hline Silesian & 173.7 & 71 & 22 & 34 & 37 \\
\hline Holy Cross & 272.3 & 43 & 38 & 38 & 5 \\
\hline Warmian-Masurian & 483.5 & 50 & 34 & 39 & 11 \\
\hline Greater Poland & 263.9 & 113 & 94 & 93 & 20 \\
\hline West Pomeranian & 347.0 & 66 & 55 & 55 & 11 \\
\hline
\end{tabular}

Source: own study based on GUS data 
Table 3

Structure of cities by size groups (as of January 1, 2019)

\begin{tabular}{|l|l|c|l|}
\hline \multirow{4}{*}{} & Total & 940 & \\
\cline { 2 - 4 } & over $1 \mathrm{mln}$ & 1 & Warszawa \\
\cline { 2 - 4 } & from 500000 to 999999 & 4 & Kraków, Łódź, Wrocław, Poznań \\
\cline { 2 - 4 } from 250000 to 499999 & 6 & Gdańsk, Szczecin, Bydgoszcz, Lublin, Białystok, Katowice \\
\cline { 2 - 4 } $\begin{array}{l}\text { Number cities } \\
\text { from } 100000 \text { to } 249999\end{array}$ & 27 & $\begin{array}{l}\text { Gdynia, Częstochowa, Radom, Toruń, Sosnowiec, Kielce, Rzeszów, Gliwice, Zabrze, } \\
\text { Olsztyn, Bielsko-Biała, Bytom, Zielona Góra, Rybnik, Ruda Śląska, Opole, Tychy, Gorzów } \\
\text { Wielkopolski, Dąbrowa Górnicza, Elbląg, Płock, Wałbrzych, Włocławek, Tarnów, Chorzów, } \\
\text { Koszalin, Kalisz }\end{array}$ \\
\cline { 2 - 4 } & from 50000 to 99999 & 46 & \\
\cline { 2 - 4 } & from 20000 to 49999 & 134 & \\
\cline { 2 - 4 } & from 10000 to 19999 & 184 & \\
\cline { 2 - 4 } & from 5000 to 9999 & 184 & \\
\hline & from 2500 to 4999 & 217 & \\
\hline & from 1000 to 2499 & 129 & \\
\hline below 1000 & 8 & \\
\hline
\end{tabular}

Source: own study based on GUS data

Table 4

Area and population of cities by voivodships (as of January 1, 2019)

\begin{tabular}{|l|c|c|c|c|c|}
\hline \multirow{2}{*}{ Specification } & Area of cit-ies in $\mathrm{km}^{2}$ & \multirow{2}{*}{$\begin{array}{c}\text { Population in cities } \\
\text { in thousands }\end{array}$} & $\begin{array}{c}\text { Urban popu-lation } \\
\text { in of the voivod- } \\
\text { ship's popu-lation }\end{array}$ & Area of cities in km2 & $\begin{array}{c}\text { Population in cities } \\
\text { in thousands }\end{array}$ \\
\cline { 4 - 6 } & 22162 & 23087.87 & 60.1 & 23.6 & 24.6 \\
\hline Poland & 2165 & 1990.50 & 68.6 & 23.8 & 21.9 \\
\hline Lower Silesian & 829 & 1227.85 & 59.1 & 15.9 & 23.6 \\
\hline Lublin & 1019 & 983.84 & 46.5 & 21.2 & 20.5 \\
\hline Lubusz & 876 & 658.92 & 64.9 & 20.4 & 15.3 \\
\hline Eódź & 1160 & 1542.68 & 62.5 & 26.4 & 35.1 \\
\hline Lesser Poland & 1659 & 1639.52 & 48.2 & 26.8 & 26.4 \\
\hline Masovian & 2190 & 3481.63 & 64.4 & 24.9 & 39.6 \\
\hline Opole & 848 & 525.85 & 53.3 & 23.6 & 14.6 \\
\hline Subcarpathian & 1234 & 881.88 & 41.4 & 24.2 & 17.3 \\
\hline Podlaskie & 925 & 718.27 & 60.8 & 23.1 & 18.0 \\
\hline Pomeranian & 1072 & 1485.79 & 63.7 & 25.5 & 35.4 \\
\hline Silesian & 3790 & 3478.79 & 76.7 & 53.4 & 49.0 \\
\hline Holy Cross & 775 & 564.82 & 45.5 & 18.0 & 13.1 \\
\hline Warmian-Masurian & 616 & 846.01 & 59.2 & 12.3 & 16.9 \\
\hline Greater Poland & 1546 & 1896.33 & 54.3 & 13.7 & 16.8 \\
\hline West Pomeranian & 1458 & 1165.18 & 68.5 & 22.1 & 17.7 \\
\hline Source: & & & & \\
\hline
\end{tabular}

Source: own study based on GUS data

and the least population per city was noted in the Holy Cross voivodship.

As of January 1, 2019, there were 1042 inhabitants per $1 \mathrm{~km}^{2}$ of Polish cities (Table 5). The most densely populated cities were Masovian (1,590 people) and Kuyavian-Pomeranian (1,481 people). The cities of the Pomeranian, Warmian-Masurian and Łódź voivodships also had a high population density (1 386, 1373 and 1330 people). In contrast, in the cities of the Opole voivodship, the population density rate was the lowest and amounted to 620 people per $1 \mathrm{~km}^{2}$. Fewer than 800 people per $1 \mathrm{~km}^{2}$ was also noted in the cities of the following voivodships: Subcarpathian, Holy Cross, Lubusz, Podlaskie and West Pomeranian.

Urban centres play an essential function in the socioeconomic system. They constitute areas of concentration of economic activity, i.e., creating added value as well as jobs. Cities are socio-economic structures organised compre-hensively, with proper spatial (visual) forms (Jacobs, 1961; Mohan, 1979; Cheshire, Nathan and Overman, 2014). Therefore, a city is considered as an economic, social, and natural system, consisting of numerous functional subsystems open to the external environment. The development of urban centres as 
Vol. 6, No. 4, 2020

Table 5

Urban population density by voivodships (as of January 1, 2019)

\begin{tabular}{|c|c|c|c|}
\hline Specification & Area of cities in $\mathrm{km}^{2}$ & Population in cit-ies in thousands & Population per $1 \mathrm{~km}^{2}$ \\
\hline Poland & 22162 & 23087.87 & 1042 \\
\hline Lower Silesian & 2165 & 1990.50 & 919 \\
\hline Kuyavian-Pomeranian & 829 & 1227.85 & 1,481 \\
\hline Lublin & 1019 & 983.84 & 965 \\
\hline Lubusz & 876 & 658.92 & 752 \\
\hline Łódź & 1160 & 1542.68 & 1330 \\
\hline Lesser Poland & 1659 & 1639.52 & 988 \\
\hline Masovian & 2190 & 3481.63 & 1,590 \\
\hline Opole & 848 & 525.85 & 620 \\
\hline Subcarpathian & 1234 & 881.88 & 715 \\
\hline Podlaskie & 925 & 718.27 & 777 \\
\hline Pomeranian & 1072 & 1485.79 & 1,386 \\
\hline Silesian & 3790 & 3478.79 & 918 \\
\hline Holy Cross & 775 & 564.82 & 729 \\
\hline Warmian-Masurian & 616 & 846.01 & 1,373 \\
\hline Greater Poland & 1546 & 1896.33 & 1,227 \\
\hline West Pomeranian & 1458 & 1165.18 & 799 \\
\hline
\end{tabular}

Source: own study based on GUS data

a system is governed by laws (Regulski, 1980), which shape the relationships between its individual elements.

\section{Quality of life in Polish cities - an attempt at evaluation}

As already indicated in the theoretical part of the study, there are numerous available methodologies related to the quality of life in cities. As an example, one can indicate the study "Uciekające metropolie" (Uciekajace...), which anal-yses large cities in Poland in a cross-sectional way, extending the analysis to functional areas. For the purposes of the study, several indicators were selected, primarily guided by the availability of statistical data (the main source of information is the Local Data Bank) and their versatility (indicators should best relate to areas related to the quality of life in the city). Thirteen indicators from the social, economic and spatial areas were selected for the study. Table 6 shows the indicators selected for analysis in more detail.

The presented analysis is simplified and presents a static view. This means that data accepted for the study related to a specific point, which was 2018. This does not reflect the scope of changes that may have occurred in a specific time perspective. Nevertheless, the simplified nature of the study presents the levels of indicators representing the quality of life in cities.

Table 7 presents the values of individual indicators adopted for the analysis.

Subsequently, these indicators were ordered according to items from the most favourable to the least favourable value of the indicator, depending on whether the indicator was specified as a stimulant or destimulant (Table 8).
Within the accepted study areas, the city of Rzeszów achieved the best result among the 18 cities surveyed in Poland. It was followed by Warsaw, Kraków, Opole, and Wrocław. Rzeszów, which belongs to the cities of East-ern Poland, occupies high positions in reports on the quality of life in Poland published by various magazines and agencies. It is a city, which, compared to other large cities, has a relatively compact structure and a small population (191000 inhabitants). In terms of population, the city is comparable to the city of Kielce, and it is not much larger than Opole, Zielona Góra or Gorzów Wielkopolski. Rzeszów was able to develop features that attract primarily new residents. The migration balance for this city in 2018 was 6.72 and was slightly higher than in the capital city of Warsaw. Rzeszów is considered a green and friendly city. In terms of entities operating in the cultural sector related to entertainment and recreation, Rzeszów is comparable with such a large and important centre as Wrocław, it is also a city with an attractive housing offer for residents or newcomers; in 2018, the number of dwellings completed was comparable with the city Kraków. The labour market data related to the number of employed persons per 1000 population are favourable. The city reached a high level compared to other large cities. According to CSO data, this number is 481 people per 1000 population, which gives Rzeszów the third position in Poland after Katowice and Warsaw, and it is a better result than one achieved in a given year in Wrocław, Poznań or Kraków. The city of Rzeszów has quite high values if we look at the spatial zone related to the number of bicycle paths per 10000 population. In this indicator, the city is unparalleled. Rzeszów can be considered a safe city on the basis of data published by 
Table 6

\section{List of indicators for evaluating the quality of life in cities}

\begin{tabular}{|c|c|c|}
\hline No. & Name of the indicator & Justification for the analysis \\
\hline $\mathrm{x}_{1}$ & Balance of migration & $\begin{array}{l}\text { Presents the direction of population movement. May reflect the potential } \\
\text { at-tractiveness of the place. }\end{array}$ \\
\hline $\mathrm{x}_{2}$ & $\begin{array}{l}\text { Entities operating in the area related to } \\
\text { culture, entertainment and recreation } \\
\text { per } 100000 \text { population }\end{array}$ & It presents new elements of the economy related to, among others with creative class. \\
\hline $\mathrm{x}_{3}$ & Dwellings completed per 1000 popula-tion & $\begin{array}{l}\text { The indicator indirectly represents the situation on the real estate market in the } \\
\text { selected city. }\end{array}$ \\
\hline $\mathrm{x}_{4}$ & Employed persons per 1000 population & $\begin{array}{l}\text { Indicator relating to the economic situa-tion of the population, indirectly reflect-ing } \\
\text { the situation on the labour market. }\end{array}$ \\
\hline $\mathrm{x}_{5}$ & $\begin{array}{l}\text { Share of the area covered by the applica-ble } \\
\text { local spatial development plans in the area in } \\
\text { total \% }\end{array}$ & $\begin{array}{l}\text { To some extent, it reflects the spatial order of the area covered by the study. As a rule, } \\
\text { a larger area covered by plans can be seen as an element stimulating development. }\end{array}$ \\
\hline $\mathrm{x}_{6}$ & $\begin{array}{l}\text { Walking and recreation parks, area in ha per } \\
1000 \text { population }\end{array}$ & $\begin{array}{l}\text { The number of green areas has become an increasingly important element in the making } \\
\text { of location decisions and affect-ing the quality of life in the city in the last decade. }\end{array}$ \\
\hline $\mathrm{x}_{7}$ & Bike paths per 10000 population & $\begin{array}{l}\text { Bike paths, especially well-designed ones, can be an important element of the quality } \\
\text { of the location; the indicator can have an impact on the elimination of car flows in } \\
\text { major parts of the city, and thus the elimination of traffic jams. }\end{array}$ \\
\hline $\mathrm{x}_{8}$ & $\begin{array}{l}\text { Children in kindergartens in total per } 1000 \\
\text { population }\end{array}$ & $\begin{array}{l}\text { Access to educational institutions is an important element affecting the quality of life } \\
\text { in the city. }\end{array}$ \\
\hline $\mathrm{x} 9$ & $\begin{array}{l}\text { Own revenues of municipal budgets per } \\
\text { capita }\end{array}$ & $\begin{array}{l}\text { Economic indicator reflecting the finan-cial potential of the city as a local gov- } \\
\text { ernment unit. }\end{array}$ \\
\hline $\mathrm{x}_{10}$ & $\begin{array}{l}\text { Doctors (total working staff) per } 10000 \\
\text { population }\end{array}$ & $\begin{array}{l}\text { A social indicator, which, to some extent, provides access to basic public services in } \\
\text { the form of healthcare. }\end{array}$ \\
\hline $\mathrm{x}_{11}$ & Beds in hospitals per 1000 population & $\begin{array}{l}\text { A social indicator, which, to some extent, provides access to basic public services in } \\
\text { the form of healthcare. }\end{array}$ \\
\hline $\mathrm{x}_{12}$ & $\begin{array}{l}\text { Total offenses recorded by the police per } 1 \\
000 \text { residents }\end{array}$ & $\begin{array}{l}\text { An indicator reflecting a crucial element affecting the quality of life in the city, which } \\
\text { is the level of security. Destimu-lant. }\end{array}$ \\
\hline $\mathrm{x}_{13}$ & $\begin{array}{l}\text { Budget expenditure on transport and } \\
\text { communication per capita }\end{array}$ & $\begin{array}{l}\text { Economic indicator partly related to the spatial zone, covering transport and } \\
\text { communication. }\end{array}$ \\
\hline
\end{tabular}

Source: own

Table 7

Value of indicators selected for analysis for large cities in Poland in 2018

\begin{tabular}{|l|c|c|c|c|c|c|c|c|c|c|c|c|c|}
\hline & $\mathrm{x}_{1}$ & $\mathrm{x}_{2}$ & $\mathrm{x}_{3}$ & $\mathrm{x}_{4}$ & $\mathrm{x}_{5}$ & $\mathrm{x}_{6}$ & $\mathrm{x}_{7}$ & $\mathrm{x}_{8}$ & $\mathrm{x}_{9}$ & $\mathrm{x}_{10}$ & $\mathrm{x}_{11}$ & $\mathrm{x}_{12}$ & $\mathrm{x}_{13}$ \\
\hline Wroclaw & 2.3 & 286.6 & 14.7 & 438 & 58.1 & 1.3 & 4.06 & 35.3 & 4966.37 & 125.3 & 8.3 & 30.63 & 1251 \\
\hline Bydgoszcz & -3.01 & 225.3 & 3.3 & 353 & 37.4 & 2.5 & 2.87 & 31.7 & 3462.25 & 134 & 9.8 & 20.6 & 1166.5 \\
\hline Toruń & -1.83 & 344.9 & 4.9 & 332 & 56.2 & 0.3 & 5.74 & 29.1 & 3201.89 & 78 & 6.4 & 25.37 & 967.1 \\
\hline Warszawa & 6.16 & 407.7 & 13.2 & 536 & 37.3 & 0.5 & 3.32 & 39.3 & 7236.69 & 145.4 & 6.9 & 26.62 & 2538.8 \\
\hline Lublin & -0.46 & 222.6 & 8.5 & 371 & 53.3 & 0.5 & 4.12 & 36.4 & 3309.1 & 198,2 & 10.8 & 19.69 & 1780.1 \\
\hline Łódź & -1.74 & 211 & 4.1 & 369 & 20.5 & 1 & 2.31 & 31.7 & 3820.43 & 121.5 & 8.6 & 21.63 & 907.3 \\
\hline Gorzów Wielkopolski & -0.53 & 220.3 & 5.8 & 328 & 56 & 1.4 & 4.08 & 36.5 & 2851.77 & 70.9 & 6.8 & 32.85 & 1056.3 \\
\hline Zielona Góra & 4.3 & 252.3 & 8.7 & 337 & 17.1 & 0.2 & 4.7 & 39.3 & 3667.71 & 74.3 & 5.9 & 31.4 & 1865.1 \\
\hline Kraków & 6.13 & 328.9 & 12.5 & 461 & 61.8 & 0.6 & 2.77 & 40 & 4679.43 & 166.5 & 8 & 23.53 & 1231.1 \\
\hline Opole & 2.09 & 318.4 & 6.2 & 476 & 28.7 & 1.4 & 7.03 & 37.1 & 4384.55 & 122.8 & 9.9 & 24.78 & 1543.2 \\
\hline Rzeszów & 6.72 & 282.9 & 12 & 481 & 16.8 & 0.4 & 8.15 & 44.4 & 3376.08 & 175.1 & 12.3 & 16.23 & 1657.5 \\
\hline Kielce & -2.96 & 271.2 & 4.6 & 390 & 17.6 & 0.4 & 2.62 & 33.4 & 3401.33 & 149.7 & 9.2 & 26.52 & 981.5 \\
\hline Białystok & -1.11 & 206.1 & 6.5 & 296 & 53.6 & 0.4 & 4.32 & 39.3 & 3363.97 & 121.4 & 8.2 & 20.66 & 1990.2 \\
\hline Poznań & -3.51 & 321.6 & 7.5 & 459 & 46.4 & 0.6 & 4.52 & 36.2 & 4558.96 & 112.2 & 10.5 & 29.39 & 1543.5 \\
\hline Szczecin & 0.59 & 263.9 & 5.7 & 295 & 53.6 & 0.4 & 3.41 & 24.8 & 3550.5 & 104.1 & 8.7 & 33.88 & 1288 \\
\hline Gdańsk & 4.23 & 253.5 & 14.7 & 395 & 65.9 & 0.5 & 3.91 & 32.1 & 4733.92 & 116.1 & 6.3 & 23.15 & 1471.6 \\
\hline Katowice & -2.55 & 281.1 & 3 & 573 & 26.3 & 0.6 & 2.63 & 33.1 & 4459.19 & 197.3 & 12.4 & 35.06 & 880.2 \\
\hline Olsztyn & -2.4 & 301.1 & 3.8 & 376 & 56 & 0.6 & 5.05 & 40.5 & 3606.38 & 104,8 & 10.2 & 22.31 & 1740.9 \\
\hline
\end{tabular}

Source: own study based on the Local Data Bank 
Vol. 6, No. 4, 2020

Table 8

Positioning of cities according to the value of the xi indicator adopted for the analysis

\begin{tabular}{|l|c|c|c|c|c|c|c|c|c|c|c|c|c|}
\hline & $\mathrm{x}_{1}$ & $\mathrm{x}_{2}$ & $\mathrm{x}_{3}$ & $\mathrm{x}_{4}$ & $\mathrm{x}_{5}$ & $\mathrm{x}_{6}$ & $\mathrm{x}_{7}$ & $\mathrm{x}_{8}$ & $\mathrm{x}_{9}$ & $\mathrm{x}_{10}$ & $\mathrm{x}_{11}$ & $\mathrm{x}_{12}$ & $\mathrm{x}_{13}$ \\
\hline Wroctaw & 6 & 7 & 1 & 7 & 3 & 4 & 10 & 11 & 2 & 10 & 11 & 14 & 11 \\
\hline Bydgoszcz & 17 & 14 & 17 & 13 & 11 & 1 & 14 & 15 & 12 & 7 & 7 & 3 & 13 \\
\hline Toruń & 13 & 2 & 13 & 15 & 4 & 17 & 3 & 17 & 17 & 16 & 16 & 10 & 16 \\
\hline Warszawa & 2 & 1 & 3 & 2 & 12 & 10 & 13 & 4 & 1 & 6 & 14 & 12 & 1 \\
\hline Lublin & 9 & 15 & 7 & 11 & 9 & 11 & 8 & 9 & 16 & 1 & 3 & 2 & 4 \\
\hline Łódź & 12 & 17 & 15 & 12 & 15 & 5 & 18 & 16 & 8 & 10 & 10 & 5 & 17 \\
\hline Gorzów Wielkopolski & 10 & 16 & 11 & 16 & 5 & 2 & 9 & 8 & 18 & 18 & 15 & 16 & 14 \\
\hline Zielona Góra & 4 & 13 & 6 & 14 & 17 & 18 & 5 & 5 & 9 & 17 & 18 & 15 & 3 \\
\hline Kraków & 3 & 3 & 4 & 5 & 2 & 6 & 15 & 3 & 4 & 4 & 13 & 8 & 12 \\
\hline Opole & 7 & 5 & 10 & 4 & 13 & 3 & 2 & 7 & 7 & 9 & 6 & 9 & 8 \\
\hline Rzeszów & 1 & 8 & 5 & 3 & 18 & 13 & 1 & 1 & 14 & 3 & 2 & 1 & 6 \\
\hline Kielce & 16 & 10 & 14 & 9 & 16 & 14 & 17 & 12 & 13 & 5 & 8 & 11 & 15 \\
\hline Białystok & 11 & 18 & 9 & 17 & 7 & 15 & 7 & 6 & 15 & 11 & 12 & 4 & 2 \\
\hline Poznań & 18 & 4 & 8 & 6 & 10 & 7 & 6 & 10 & 5 & 13 & 4 & 13 & 7 \\
\hline Szczecin & 8 & 11 & 12 & 18 & 8 & 16 & 12 & 18 & 11 & 15 & 9 & 17 & 10 \\
\hline Gdańsk & 5 & 12 & 2 & 8 & 1 & 12 & 11 & 14 & 3 & 12 & 17 & 7 & 9 \\
\hline Katowice & 15 & 9 & 18 & 1 & 14 & 8 & 16 & 13 & 6 & 2 & 1 & 18 & 18 \\
\hline Olsztyn & 14 & 6 & 16 & 10 & 6 & 9 & 4 & 2 & 10 & 14 & 5 & 6 & 5 \\
\hline
\end{tabular}

Source: own study

the Central Statistical Office. In terms of the number of crimes registered by the police, it reaches the lowest rates among the largest Polish cities. In terms of healthcare, the city of Rzeszów also looks favourable. Total number of doc-tors per 10000 population is 175 , and it is a high value compared to other cities, which gives the city of Rzeszów the second position after Lublin (which reached the value of 198).

Among the analysed cities, Rzeszów was most often above the average value of the xi index, up to ten times. The cities of Kraków, Opole, Warsaw, Poz-nań, Wrocław, Lublin, and Olsztyn were slightly above average. The cities of Łódź and Kielce were the above average the least number of times, i.e., only twice, while Szczecin was at the end of the ranking.

\section{Conclusion}

This article presents the issue of quality of life in cities. The research goal set out at the beginning of the study was achieved by analysing selected indicators regarding the quality of life in relation to 18 large Polish cities.

The quality of life in the city has always been an element that directly or indirectly influences its development. Especially in the last decade, one can observe the intensifying tendency of people to live in cities, especially large cities and metropolises. This raises a number of problems regarding how to manage such highly urbanised areas, as well as the escalation of new problems. Therefore, improving the quality of life is becoming one of the main strategic goals of sustainable development, and in practice it is included in numerous Polish strategies for the development of
Table 9

City positions taking into account the highest level of indicators selected for the survey in 2018

\begin{tabular}{|c|c|c|}
\hline $\begin{array}{c}\text { Ranking } \\
\text { position }\end{array}$ & City & $\begin{array}{c}\text { Frequency of the above- } \\
\text { mentioned 13 indicators } \\
\text { above aver-age }\end{array}$ \\
\hline 1 & Rzeszów & 10 \\
\hline 2 & Warszawa & 8 \\
\hline 3 & Kraków & 9 \\
\hline 4 & Opole & 9 \\
\hline 5 & Wrocław & 7 \\
\hline 6 & Lublin & 7 \\
\hline 7 & Olsztyn & 7 \\
\hline 8 & Poznań & 8 \\
\hline 9 & Gdańsk & 6 \\
\hline 10 & Białystok & 4 \\
\hline 11 & Katowice & 5 \\
\hline 12 & Bydgoszcz & 4 \\
\hline 13 & Zielona Góra & 5 \\
\hline 14 & Gorzów Wielkopolski & 3 \\
\hline 15 & Toruń & 3 \\
\hline 16 & Łódź & 2 \\
\hline 17 & Kielce & 2 \\
\hline 18 & Szczecin & 1 \\
\hline
\end{tabular}

Source: own study

local government units. Quality of life is also becoming one of the most important aspects when making decisions about where to live (access to work is not the only important factor), as well as numerous location decisions for domestic and foreign business entities.

In the last few decades, the Polish cities have undergone a number of changes. One of the 
most important is the political transformation or administrative reform of 1999. Cities flexible enough to quickly adapt to changes have been coping with it the best. Flexibility and adaptability are the extremely desirable features in the second decade of the 21 st century in the context of challenges created by globalisation or climate change.

The study presents an analysis of the quality of life of the large Polish cities based on selected 13 indicators.
The best results were achieved not only by large economically significant cities, attracting investments and residents, but also those located on the eastern wall of the country, which can be described as "more intimate" in terms of area and population, such as Rzeszów, Lublin or Olsztyn. In this study, an additional goal is a detailed presentation of the demographic situation of the Polish cities, which illustrates the trends in the changes of area and population of the cities.

\section{References:}

Local Data Bank, GUS.

Boryczka, E. M. (2019). Procesy rewitalizacji i ich konsekwencje dla przekształceń bazy ekonomicznej miasta. Przykład miast poprzemysłowych. Rozprawa doktorska. Łódź: Uniwersytet Łódzki.

Borys, T. (2003). Jakość życia jako integrujący rodzaj jakości. In: J. Tomczyk-Tołkacz (ed.). Jakość życia w perspektywie nauk humanistycznych, ekonomicznych i ekologii. Jelenia Góra: Wydawnictwo Akademii Ekonomicznej im. Oskara Langego we Wrocławiu.

Brol, R. (2001). Rozwój miasta. In: R. Brol (ed.). Ekonomika i zarządzanie miastem. Wrocław: Wydawnictwo Akademii Ekonomicznej im. Oskara Langego we Wrocławiu.

Cheshire, P. C., Nathan, M. \& Overman, H. G. (2014). Urban Economics and Urban Policy. Challenging Conventional Policy Wisdom. Cheltenham: Edward Elgar Publishing.

Costanza, R., Fisher, B., Ali, S. i in. (2008). Integrative approach to quality of life meas-urement, research, and policy. S.A.P.I.E.N.S, 1(1), p. 18.

Diener, E. \& Suh, E. (1997). Measuring quality of life: Economic, social, and subjective indicators. Social Indicators Research, 40, p. 200.

European Commission (2010). Europe 2020 - A Strategy for Smart, Sustainable and In-clusive Growth. COM (2010) 2020 final.

Florida, R. (2010). Narodziny klasy kreatywnej oraz jej wpływ na przeobrażenia w charakterze pracy, wypoczynku, społeczeństwa i życia codziennego (tłum. T. Krzyżanowski, M. Penkala). Warszawa: Narodowe Centrum Kultury. Główny Urząd Statystyczny [GUS] (2018). Miasta w liczbach 2016. Warszawa, Poznań: Główny Urząd Statystyczny

Główny Urząd Statystyczny [GUS] (2019). Powierzchnia i ludność w przekroju terytorialnym w 2019 r. Warszawa: Główny Urząd Statystyczny.

International Definition and measurement of levels of living. An Interim Guide (1961). United Nations, E/CN.3/270/Rev.1, E/CN.5/353, New York.

Jacobs, J. (1961). The Death and Life of Great American Cities. New York: Random House.

Klasik, A. (ed.). (2008). Aktywność przedsiębiorcza i konkurencyjność ekonomiczna miast w procesie restrukturyzacji aglomeracji miejskich. Katowice: Wydawnictwo Akademii Ekonomicznej w Katowicach.

Koncepcja Przestrzennego Zagospodarowania Kraju 2030, 2011. M.P. 2012 poz. 252, Uchwała Nr 239 Rady Ministrów z dnia 13 grudnia 2011 r. w sprawie przyjęcia Koncepcji Przestrzennego Zagospodarowania Kraju 2030. Konecka-Szydłowska, B. (2017). Zróżnicowanie poziomu rozwoju społeczno-gospodarczego nowych miast. Przykład Polski i Węgier. Studia Ekonomiczne. Zeszyty Naukowe Uniwersytetu Ekonomicznego w Katowicach (327).

Korcelli, P. (2007). Podstawowe węzły układu osadniczego Polski na tle europejskiego systemu osadniczego (aglomeracje-metropolie). Biuletyn KPZK PAN, (233), pp. 87-113.

Kosecki, A. \& Stawarz, A. (eds.) (2005). Tożsamość społeczno-kulturowa współczesnego miasta w Polsce. Warszawa-Pultusk: PTEM.

Kot, S. M. (2004). Rozkłady dochodów, nierówności i dobrobyt w Polsce. W: S.M. Kot, A. Makowski, A. Węgrzecki (eds.). Dobrobyt społeczny, nierówności i sprawiedliwość dystrybutywna. Kraków: Wydawnictwo Akademii Ekonomicznej w Krakowie.

Królikowska-Tomczak, A. (2016).Zarządzanie zrównoważonym rozwojem turystyki a jakość życia w aglomeracjach miejskich. Handel wewnętrzny, 6(365), p. 361.

Mohan, R. (1979). Urban Economic and Planning Models. World Bank Staff Occasional Papers, (25), pp. 6-10.

Panek, T. \& Zwierzchowski, J. (2019). Analiza porównawcza jakości życia w Polsce w układzie wojewódzkim w ramach podejścia możliwości. Zeszyty Naukowe Instytutu Statystyki i Demografii Szkoły Głównej Handlowej w Warszawie nr 51. Warszawa: SGH w Warszawie.

Regulski, J. (1980). Rozwój miast w Polsce. Warszawa: PWN.

Rogerson, R. J. (1999). Quality of life and city competitiveness. Urban Studies, 36 (5-6), p. 969-985. 
Sanetra-Szeliga, J. (2017). Kultura jako element składowy jakości życia w mieście. W: J. Hausner, (red.). Kultura i rozwój, 1(2). Warszawa: Wydawnictwo Naukowe Scholar.

Szewczuk, A. (2011). Rozwój lokalny i regionalny - główne determinanty. In: A. Szewczuk, M. Kogut-Jaworska, M. Zioło (ed.). Rozwój lokalny i regionalny. Teoria i praktyka. Warszawa: Wydawnictwo C.H. Beck.

Throsby, D. (2010). Ekonomia i kultura, Warszawa: Narodowe Centrum Kultury.

Uciekajace metropolie. Ranking 100 polskich miast, Klub Jagielloński, Kraków 2019.

Wałachowski, K. (2019). Uciekające metropolie. Ranking 100 polskich miast. Raport 09/2019. Kraków: Klub Jagielloński.

Yuan, L. L., Yuen, B. i Low, C. (1999). Urban quality of life - critical issues and options. Singapore: National University of Singapore.

Zaniewska, H. (2014). Rozmieszczenie przestrzenne i cechy nowych małych miast z przełomu XX i XXI w. Problemy Rozwoju Miast. Kwartalnik Naukowy Instytutu Rozwoju Miast w Krakowie, (11/3), p. $75-83$. 